\title{
59. Heteroecism of the Wistaria Rust, Ochropsora kraunhiae (Diet.) Dietel*)
}

\author{
By Naohide Hiratsuka, M. J. A., and Shigeru Kaneko \\ The Tottori Mycological Institute, Tottori \\ (Communicated June 15, 1978)
}

The authors experimentally clarified that the aecial state of the Wistaria rust, Ochropsora kraunhiae (Diet.) Dietel is Aecidium corydalinum P. et H. Sydow.

P. Dietel (1902) described newly a species, Phakopsora (?) kraunhiae (Melampsoraceae), on the basis of a specimen of the uredinial and telial states of the rust fungus on leaves of Wistaria floribunda (Willd.) DC. (Kraunhia floribunda Willd.) (Leguminosae) collected by T. Nishida in Tokyo. Then, he (1905) transferred this species into the genus Ochropsora, naming Ochropsora kraunhiae (Diet.) Dietel.

P. Hennings (1900) identified the aecial state of a rust fungus on leaves of Corydalis incisa (Thunb.) Pers. (Papaveraceae) as Aecidium dicentrae Trel., which was collected by M. Shirai at Nikko, Tochigi Pref. Thereafter, P. and H. Sydow (1923) described this fungus on Corydalis incisa as a new species, Aecidium corydalinum (Uredinales Imperfecti).

Systemic mycelia of Aecidium corydalinum on Corydalis produce spermogonia all over the under surface of leaves of shoots infected in spring, and the aecia are produced subsequently. Y. Hiratsuka and G. B. Cummins (1963) divided the morphological type of spermogonia of rust fungi into 11 types, and showed that within most genera, the spermogonia are constant as to morphological type, and closely related genera tend to have spermogonia of the same or related types. The spermogonia of Aecidium corydalinum (Figs. 1 and 2) are subcuticular, determinate growth, and have flat hymenia with peridia. The spermogonium type of this rust fungus applies to type 7 of Hiratsuka and Cummins' division. Depending on Hiratsuka and Cummins, 21 genera of the rust fungi including the genus Ochropsora, have type 7 spermogonium. In several places at Tottori district where Aecidium corydalinum frequently occurs, it is considered that Ochropsora kraunhiae is the only species that has type 7 spermogonium and moreover heteroecious life cycle. By the reason mentioned above, it was suspected that there might be a genetic connection between Aecidium

*) Contributions to the Tottori Mycological Institute, No. 126. 
corydalinum on Corydalis and Ochropsora kraunhiae on Wistaria, and inoculation experiments with aeciospores on Corydalis incisa onto Wistaria floribunda were conducted. On May 2, 1977, numerous aecia of Aecidium corydalinum on Corydalis incisa were collected by the authors at Kokoge, Tottori-city, Western Honshu of Japan. On the same day, the aeciospores from leaves of Corydalis were sown on the leaves of Wistaria floribunda which grew outdoors, and were kept humidity for $24 \mathrm{hr}$ in vinyl bags. After 28 days, uredinia began to appear on the inoculated leaves. Second experiment was carried out, using potted Wistaria. The authors collected Aecidium corydalinum on Corydalis incisa at Kokoge on June 1 of the same year. On the same day, inoculations with the aeciospores from Corydalis were performed onto Wistaria potted in $20^{\circ} \mathrm{C}, 100 \%$ humidity condition for $24 \mathrm{hr}$, and they were kept in a glass house. Sixteen days after the inoculations, numerous uredinia began to appear on the leaves, and on October 5, 1977, viz. 110 days after the inoculations, telia developed on the reverse side of the leaves. Without resting period, the teliospores turned into internal basidia and produced basidiospores under moisture condition. The morphological characters of the uredinial and telial states which were produced through cultures coincided with those of Ochropsora kraunhiae (Diet.) Dietel.

The return inoculations to Corydalis incisa were conducted with basidiospores from basidia produced by cultures on the leaves of Wistaria floribunda. On November 7, 1977, telia producing basidiospores were placed on the leaves of 17 potted Corydalis, and were kept in $10-20^{\circ} \mathrm{C}, 100 \%$ humidity for 7 days. After then, the inoculated plants were kept in a laboratory room $\left(10-20^{\circ} \mathrm{C}\right)$. Positive results were obtained on all inoculated plants, while no infection was observed on uninoculated ones for control. From 20 to 30 days after the basidiospore inoculations, the petioles of inoculated leaves began to twist a little. In those petioles, many hyphae were observed. These hyphae sometimes had branches (Fig. 8). In the very first case, systemic spermogonia appeared 42 days after the inoculations on the under surfaces of newly developing leaves, and 17 days after appearance of the spermogonia aecia were produced. More spermogonia were produced one after another on newly developing leaves, and occurrence of aecia followed it. In several cases, spermogonia appeared after the development of new leaves. The above-mentioned results have proved that the aecial state of Ochropsora kraunhiae (Diet.) Dietel is exactly Aecidium corydalinum P. et H. Sydow itself. 

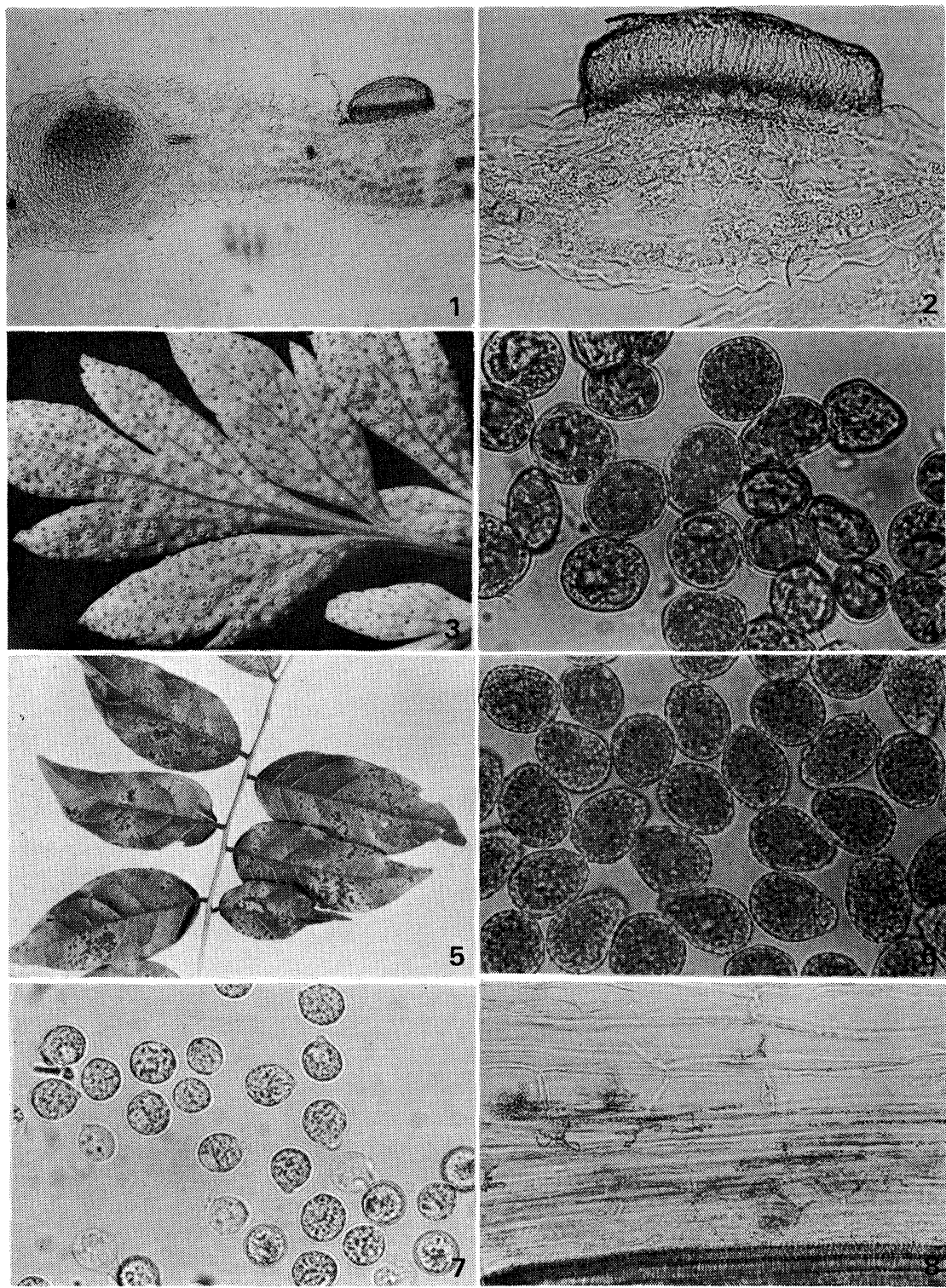

Figs. 1-8. Ochropsora kraunhiae (Diet.) Dietel. 1: Vertical section of a spermogonium and an immature aecium on Corydalis incisa (Kokoge, Tottori-shi, April 30, 1977, S. Kaneko, HH-97416). $\times 80$. 2: Vertical section of a spermogonium $(\mathrm{HH}-97416) . \times 270$. 3: Aecia and spermogonia. $\times 4$. 4: Aeciospores (HH-97416). $\times 800$. 5: Uredinia on Wistaria floribunda (Kokoge, Tottori-shi, June 30, 1977, S. Kaneko, cultures, HH-97417). $\times 1.5$. 6: Urediniospores $(\mathrm{HH}-97417) . \times 800$. 7: Basidiospores from teliospores on Wistaria floribunda (Nov. 7, 1977, S. Kaneko, cultures). $\times 800$. 8: Vertical section of a petiole of a leaf inoculated with basidiospores. $\times 270$. 
Ochropsora kraunhiae (Diet.) Dietel in Bot. Jahrb. 37: 106, 1905; Hiratsuka, f., Melampsorac. Nippon. p. 251; List of Ured. Jap. p. 216; S. Ito, Mycol. Fl. Jap. 2(2) : 226; P. and H. Sydow, Monogr. Ured. 3: 666.

SYN. Phakopsora (?) kraunhiae Dietel in Hedwigia 41: (178), 1902; Saccardo, Syll. Fung. $17: 267$.

Aecidium corydalinum P. et H. Sydow, Monogr. Ured. 4: 235, 1923; Hiratsuka, f., List of Ured. Jap. p. 283; S. Ito, Mycol. Fl. Jap. 2(3) : 366; Saccardo, Syll. Fung. 23 : 905.

Aecidium dicentrae (non Trel.) Hennings in Bot. Jahrb. 28: 264, 1900.

HAB. O, I. on Corydalis ambigua Cham. et Schlecht. (Ezo-engosaku). Hokkaido (Ishikari).

O, I. on Corydalis decumbens (Thunb.) Pers. (Jirobo-engosaku). Shikoku (Tokushima).

O, I. on Corydalis incisa (Thunb.) Pers. (Murasaki-keman). Northern Honshu (Fukushima). Central Honshu (Tochigi, Chiba, Tokyo, Kanagawa, Yamanashi, Kyoto). Western Honshu (Tottori). Shikoku (Kochi). Kyushu (Fukuoka, Kumamoto, Kagoshima).

O, I. on Corydalis pallida (Thunb.) Pers. (Furo-keman). Shikoku (Kochi). Kyushu (Fukuoka, Kumamoto).

O, I. on Corydalis pallida (Thunb.) Pers. var. tenuis Yatabe (Miyamaki-keman). Central Honshu (Tokyo).

II, III. on Wistaria brachybotrys Sieb. et Zucc. (Yama-fuji). Central Honshu (Tochigi, Saitama, Kanagawa). Western Honshu (Tottori, Shimane). Kyushu (Fukuoka, Miyazaki).

II, III. on Wistaria brachybotrys Sieb. et Zucc. forma alba (W. Mill.) Hurusawa (Shira-fuji) (Cultivated). Kyushu (Miyazaki).

II, III. on Wistaria floribunda (Willd.) DC. (Fuji). Northern Honshu (Yamagata, Fukushima). Central Honshu (Niigata, Tochigi, Chiba, Saitama, Tokyo, Kanagawa, Yamanashi, Fukui, Wakayama, Hyogo). Western Honshu (Okayama, Tottori, Hiroshima). Shikoku (Tokushima, Kochi). Kyushu (Fukuoka, Oita, Kumamoto, Nagasaki, Miyazaki, Kagoshima).

DISTRIB. Japan.

The present species is endemic to the Japanese Archipelago.

\section{References}

Dietel, P. (1902) : Einige Uredineen aus Japan. Hedwigia, 41, (177)-(178). (1905) : Uredineae japonicae VI. Bot. Jahrb., 37, 97-109.

Hennings, P. (1900): Fungi japonici I. Ibid., 28, 259-280.

Hiratsuka, Naohide (1960): A provisional list of Uredinales of Japan proper and the Ryukyu Islands. Sci. Bull. Div. Agr., Home Econ. and Engin., Univ. Ryukyus, 7, 189-314.

Hiratsuka, Y., and Cummins, G. B. (1963) : Morphology of the spermogonia of the rust fungi. Mycologia, 55, 487-507.

Ito, S. (1938): Mycological flora of Japan, 2(2), 249 pp. (in Japanese). (1950) : Ibid., 2(3), 435 pp. (in Japanese).

Sydow, P. and H. (1912-1915) : Monographia Uredinearum, 3, $726 \mathrm{pp}$.

— (1923-1924) : Ibid., 4, 671 pp. 